\title{
ECONOMIC DIVERSIFICATION AND AGRO-FOOD TECHNOLOGICAL SOLUTIONS IN NIGERIA: LESSONS FROM MALAYSIA
}

\author{
Okechukwu Chilokwu \\ Nnamdi Azikiwe University, Awka \\ Egor Hikarofem \\ Nnamdi Azikiwe University, Awka \\ $\boldsymbol{\&}$ \\ Sotonye George \\ Nnamdi Azikiwe University, Awka
}

\begin{abstract}
The paper x-rayed the various aspects of the agro-food economic diversification in Malaysia to draw lessons for Nigeria's agricultural economic growth and development. A descriptive statistical method was employed in the presentation. With a total population of 31.6 million people, Malaysia has been able to harness the factor endowments for its people such that its GDP per capita (USD, PPP) grew from 18,577 in 2005 to 25,669 in 2016, whereas Nigeria's GDP per capita (USD, PPP) grew from 4,149 in 2005 to 5,435 in 2016. Nigeria failed in its capacity utilization of the available factor endowments. In 2016, the percentage of prevalence of undernourishment of Malaysian people was 2.9, while Nigeria's data was $11.5 \%$. Furthermore, there was no prevalence of severe food insecurity in Malaysia, but Nigeria recorded $24.8 \%$ in its prevalence of severe food insecurity, within the period under consideration. The paper concluded that Nigeria's economic performances are dwindling. It was recommended that to enhance stable and viable sustainable and economic growth for its people, Nigeria's mono-economy must give way to the productive development of all sectors of the economy, particularly the agro-technology.
\end{abstract}

Keywords: Diversification, resources, agro-technology, Malaysia, Nigeria

\section{Introduction}

A diversified economy is an economy that has several different revenue streams and provides the nation with the capacity for sustainable growth because there is non-reliance on one particular type of stream of revenue. Economic diversification is embedded in what is known as economic complexity, which is the idea that countries should not be dependent upon a small number of products for their economic livelihoods. Diversification thus provides nations with the security and reliability that they need so that, should one economic revenue stream fails, they have several other options for revenue. Economic diversification demands active participation in a wide range of sectors, and firmly integrated into different regions, and nations with such growth and great potential to increase resilience and contribute to achieving and sustaining long economic growth and development (Uzonwanne, 2015). But this is not the case with Nigeria, which has depended on oil revenue from 1970 till date.

The structure of the economy of Nigeria remains highly import-dependent, consumptiondriven and undiversified. Nigeria has a large expanse of agricultural land. This constitutes 77.7 per cent of Nigeria's total land area which is 910.8 thousand square kilometres. Of this total, 
37.3 per cent is arable land, 7.4 per cent is under permanent crop and 9.0 per cent is under forest (World Bank, 2016). It includes four sub-sectors, namely; crop, livestock, fishery and forestry. The crop sub-sector accounts for about $90 \%$ of agricultural production in Nigeria, followed by the livestock sub-sector which contributes about $7 \%$. Fishing activities contribute $2 \%$ and forestry activities account for $1 \%$ (NBS, 2015). Most importantly, Nigeria's agriculture presents various opportunities, which are yet to be exploited, unlike Malaysian agriculture. The Malaysian economy is diversified along with the real sector including agriculture.

The agricultural sector had been the mainstay of the Malaysian economy for many years since the country gained its independence from England in 1957. Malaysia is well-endowed with natural resources in areas such as agriculture, forestry and minerals. It is an exporter of natural and agricultural resources. In the agricultural sector, Malaysia is one of the top exporters of natural rubber, palm oil, which together with timber and timber products, cocoa, pepper, pineapple and tobacco dominate the growth of the sector (ANZ Business, 2015). As at 2011, in Malaysia, croplands consist of $17.49 \%$ while other land uses consist of $77.07 \%$ irrigated land covers $3,800 \mathrm{~km}^{2}$ and total renewable water resources make up 580 cubic $\mathrm{km}$. in 2013 , the agricultural sector contributed more than $23 \%$ of the total export earnings and adds about $7.2 \%$ of Malaysia's GDP. Agriculture is now a minor sector of the Malaysian economy contrasting with the 1960s when agriculture accounted for 37\% of Malaysia's GDP and employed $66.2 \%$ of the labour force. The crops grown by the agricultural sector has also significantly shifted to industrial crops like palm oil and rubber.

Despite its minor contribution to Malaysia's GDP, Malaysia has a significant foothold in the world's agricultural sector, being the world's second-largest producer of palm oil in 2012 producing 18.79 million tonnes of crude palm oil on 19,000 square meters of land. The economy has diversified beyond agriculture and primary commodities, so that manufactured goods now account for a much larger share of GDP and total exports. Diversification efforts in agriculture saw the successful establishments of oil palm and cocoa. It is through these primary agricultural commodities that Malaysia accumulated its early wealth to finance the development of the other sectors of the economy, namely the industrial and service sectors (Ahmad and Suntharalingam, 2009).

\section{Review of related literature}

\section{Managerial theories of firm: Marris and Williamsons theory}

In recent years, new theories of the firm have been developed which emphasize the role of managers and their behavioural patterns in establishing price and output under oligopolistic market conditions. Generally, the managers do not try to maximize profits but they pursue other goals. Whether the firm tries to maximize profits also depends upon who controls the business conducted by them. In the case of sole trader and partnership, it is the owners themselves who take price and output decisions and perform other entrepreneurial functions. In the case of jointstock companies or corporations, there is a separation between ownership and management. It is the shareholders who are the owners of a joint-stock company and bear the risks of the business. But price and output decisions are taken by the hired managers who are not the owners of the business. Under these conditions, profits of the business go to the shareholders.

The owner-entrepreneurs of sole trader and partnership are trying to maximize their profits since it is in their interest to do so. But hired managers of joint-stock companies cannot be expected to try to maximize profits since these profits do not go to them. It may be true that 
when managers can earn more profits for shareholders, they may be rewarded by them in some form or the other. The important managerial theories of the firm which have been developed in recent years are managerial theories of Marris and O.E. Williamson. Like the sales maximization theory of Baumol, managerial theories also do not admit the validity of the profit maximization hypothesis regarding the working of the business firms. According to Baumol, the managers of the firms are aiming to maximize sales revenue subject to a minimum profit level.

All these managerial theories are emphasizing the role of a manager and his seeking selfinterest while making decisions regarding price, output, sales, etc. of the corporate firms. Since the managers of corporate firms are motivated by considerations other than the maximization of profits, their decisions regarding price, output, sales, etc. are likely to be different from those of the profit-maximizing firm.

\section{Marris' managerial theory of firm:}

R. Marris has put forward an important theory of the firm according to which managers do not maximize profits but instead, according to him, they seek to maximize a balanced rate of growth of the firm. Maximization of a balanced rate of growth of the firm means maximization of the rate of growth of demand for the products of the firm and rate of growth of capital supply. If $G$ stands for balanced growth, $G_{d}$ for the growth rate of demand for the product, $G_{C}$ for the rate of growth of the capital supply, then the goal of the manager is to maximize G, Thus $\mathrm{G}=\mathrm{G}_{\mathrm{d}}=\mathrm{G}_{\mathrm{C}}$

\section{In seeking to maximize the balanced growth rate, a manager faces the following two constraints:}

1. Managerial Constraint

2. Financial Constraint

Managerial constraint refers to the strength of the managerial team and their skills. Financial constraint refers to the following three financial ratios:

1. Ratio of debt (D) to total assets (A) which is simply called debt ratio (D/A).

2. Liquidity ratio which is the ratio of liquid assets of the firm to the total assets (L/A).

3. Retention ratio $\left(\pi_{\mathrm{r}} / \pi\right)$ which refers to the ratio of retained profits to the total profits.

It is important to note that these financial variables determine the job security of the managers, if these financial ratios set by the manager crosses prudent limits, they expose the firm to the risk of being taken over by others or the mangers can be dismissed which can endanger their job security. Therefore, financial constraints are associated with job security. Managers take into account job security while making business decisions.

On the other hand, the utility of owners depends on the growth of capital supply which is positively correlated with the growth of profits. Thus, owner's utility function can be written as $-\mathrm{U}_{\text {owners }}=f\left(\mathrm{G}_{\mathrm{C}}\right)$.

\section{Under the Marris model, a manager works under two constraints:}

(i) Managerial constraint set by the decision-making capacity of the managerial team and

(ii) Financial constraint determined by three financial ratios which are reflected in the job security of the managers.

It is usually argued by managerial theorists that the division of ownership and management allows the managers to set goals which do not necessarily coincide with those of owners. The utility function of managers includes variables such as salaries, status, power and job security, while the utility function of owners includes variables such as profits, size of output, size of 
capital, the share of the market and public image. Thus, managers want to maximize their utility.

$\mathrm{U}_{\mathrm{m}}=f^{*}$ (salaries, power, status, job security)

While the owners seek the maximization of their utility

$\mathrm{U}_{\mathrm{o}}=f^{*}$ (profits, capital, output, market share, public esteem).

Marris argues that the difference between the goals of managers and the goals of the owners is not as wide as other managerial theories claim, because most of the variables appearing in both functions are strongly correlated with a single variable - i.e., size of the firm. There are various other measures (indicators) of size- capital, output, revenue, market share and there is no consensus about which of these measures is the best. Furthermore, Marris argues that the managers do not maximize the absolute size of the firm (however measured), but the rate of growth (= change of the size) of the firm. The size and the rate of growth are not necessarily equivalent from the point of view of managerial utility.

If they were equivalent we would observe high mobility of managers between firms - the managers would be indifferent in choosing between being employed and promoted within the same growing firm (enjoying higher salaries, power and prestige), and moving from a smaller firm to a larger firm where they would eventually have the same earnings and status. In the real world, the mobility of managers is low. Hence, managers aim at the maximization of the rate of growth rather than the absolute size of the firm.

The utility function of owners can be written as follows -

$\mathrm{U}_{\text {owners }}=f\left(\mathrm{G}_{\mathrm{c}}\right)$

where $\mathrm{G}_{\mathrm{c}}=$ rate of growth of capital.

It is not clear why owners should prefer growth in profits unless $G_{c}$ and profits are positively related.

\section{The managerial constraint:}

Marris adopts Penrose's thesis of the existence of a definite limit on the rate of efficient managerial expansion. At any one-time period, the capacity of the top management is given there is a ceiling to the growth of the firm set by the capacity of its managerial team. The managerial capacity can be increased by hiring new managers, but there is a definite limit to the rate at which management can expand and are main competent (efficient). Penrose's theory is that decision-making and the planning of the operations of the firm are the results of teamwork requiring the co-operation of all managers. Co-ordination and co-operation require experience. A new manager requires time before he is fully ready to join the teamwork necessary for the efficient functioning of the organization. Thus, although the 'managerial ceiling' is receding gradually, the process cannot be speeded up. Similarly, the 'research and development' (R\&D) department sets a limit to the rate of growth of the firm. This department is the source of new ideas and new products which affect the growth of demand for the products of the firm. The work in the R\&D department is 'teamwork' and as such, it cannot be expanded quickly, simply by hiring more personnel for this section - new scientists and designers require time before they can efficiently contribute to the teamwork of R\&D department.

The managerial constraint and the $R \& D$ capacity of the firm set limits both to the rate of growth of demand $\left(\mathrm{G}_{\mathrm{D}}\right)$ and the rate of growth of capital supply $\left(\mathrm{G}_{\mathrm{c}}\right)$. 


\section{The job security constraint:}

The desire of managers for security is reflected in their preference for service contracts, generous pension schemes, and their dislike for policies which endanger their position by increasing the risk of their dismissal by the owners (that is, the shareholders or the directors they appoint). Marris suggests that job security is attained by adopting a prudent financial policy. The risk of dismissal of managers arises if their policies lead the firm towards financial failure (bankruptcy) or render the firm attractive to take-over raiders. In the first case, the shareholders may decide to replace the old management in the hope that by appointing new management the firm will be run more successfully. In the second case, if the take-over raid is successful, the new owners may well decide to replace the old management.

\section{Williamson's managerial theory of the firm:}

A full-fledged managerial theory of the firm has been put forward by O.E. Williamson who emphasizes that managers are motivated by their self-interest and they maximize their utility function. Again, the objective of utility maximization by the managers is subject to the constraint that after-tax profits are large enough to pay acceptable dividends to the shareholders and also to pay for economically necessary investments.

It may, however, be pointed out that utility maximization by the self-interest seeking managers, like sales maximization model of William Baumol is possible only in a corporate form of business organization where there exists a separation between ownership and management.

\section{Import substitution versus export-oriented growth}

The early manufacturing industries-primary processing ones-that grew were those that had some natural protection because of high transportation costs and location advantages. Peninsular Malaysia had developed a comparative advantage in resource-based manufacturing industries, and its imports were more capital-intensive and export more labour-intensive in the latter period (Hoffman and Tan 1980).

Industrialization was fuelled by a combination of state intervention in the economy and the growth of a public enterprise, the use of fiscal policy and incentives to attract foreign direct investment (FOI), and the provision of industrial infrastructure and low-cost labour. The early import substitution phase gave way to an explicit export-oriented industrialization strategy. Within 20 years the economy had to adapt toa labour shortage economy, and the new phase of industrialization relied much less on labour-intensive manufacturing industries.

Diversification has reduced the importance of agriculture in the economy and has-raised the manufacturing and services sectors. Services also expanded as the economy became increasingly industrialized and accounted for the largest share of GDP. Excluding government services, financial services and wholesale and retail trade are the two largest subsectors in services. While growing, exports of services still account for a small share of total exports. Diversification of services is ongoing as more high value-added services like information and communications technology, education and tourism have expanded. Manufacturing-related services have also expanded with the rise of the manufacturing sector.

\section{Industrial policies for export-led growth}

The government played a key part in the diversification of the economy either directly or indirectly by channelling resources for diversification. Since the 1970S public investment and intervention were also used for distributive purposes (i.e. correcting ethnic imbalances in 
income, ownership, employment and entrepreneurship). Public investment increased to the early 1980s. Public investment (capital formation) was about 14 per cent of GDP in 1985 and 12.3 per cent in 1991; it then rose slightly from 1992 to 1993 but fell to about 11.3 per cent by 2000.

Private investment's share of GDP was about 15.8 per cent in $1985,31.8$ per cent in 1997 and 11 per cent in 2000. Private investment after that has been sluggish following the impact of the Asian financial crisis.

The government created a fiscal stimulus through public investment to counteract the economic slowdown after 2000, and public investment's share of GDP increased to about 18.6 per cent in 2002 and fell to an estimated 15.6 per cent in 2007. Private investment performance was dismal as its share of GDP was 10.6 per cent of GDP in 2002; it rose to 12.9 per cent in 2007, but that was less than half of its share in the peak years between 1995 and 1997.

Foreign direct investment (FDI) has played a central role in the diversification of the economy. Overall Malaysia has kept its economy relatively open. FDI was instrumental in the growth of agriculture and mining, and it also helped diversify the economy away from the cultivation of rubber into palm oil. British investment in rubber plantations started in the late nineteenth century, and diversification into palm oil was encouraged through replanting grants and utilizing a cess tax on rubber. Indigenous rubber smallholders also had access to the replanting grants.

Malaysia adopted an industrial policy approach for its export-led growth for manufacturing industries. It supported exporters by providing tax holidays and creating export processing zones. The government also used tariffs, import restrictions and government procurement of locally produced goods. These policies helped promote exports and protect domestic manufacturers. Early in this approach, the government promoted industries that could replace or reduce the number of manufactured products that were imported and also to support resource-based manufacturing industries.

\section{Rubber replanting}

From 1948 to 1952, rubber accounted for almost 70 per cent of the total output value of the major agricultural commodities. From 1963 to 1967 its share declined to about 65 per cent of total agricultural output while as a share of GNP it fell from 38 per cent to 15 per cent (Lim, 1973). The successful diversification strategy comprised several elements, especially through research and development, and the role of the Rubber Research Institute of Malaysia (RRIM) was crucial in this regard. Replanting schemes for rubber essentially were programs for the reinvestment of profits of rubber estates and smallholdings.

\section{Palm oil diversification and investment}

Before Malaysia became the world's leading producer of palm oil, West Africa was the most important producing region ( $\mathrm{Lim}, 1967)$. A new phase commenced in 1957 when the government became more active in investing in palm oil through FELDA. Before World War Two, oil palm was entirely an estate crop. In the first half of the 1970s, FELDA planted oil palms on about 288,000 acres. Almost 90 per cent (3.6 million hectares) of the total planted acreage in 2005 was matured acreage compared with 86 per cent in 1990 and 75 per cent in 1970. 


\section{Manufacturing export-led growth}

Financial resources were used for infrastructure development promoting industrial estates and warehouses). Fiscal incentives (mostly tax incentives and larger ownership shares) were utilized to attract FDI, especially those involved in manufactured exports. Such exports became a major contributor to economic growth, accounting for more than 70 per cent of total exports, by the late 19805 and with the non-resourced-based industries dominating exports.

Diversification through the reform clusters approach illustrates policymaking, leadership and learning within the specific industrial contexts. Four manufacturing industries provide insights into the continuing push for diversification: rubber and palm oil products (both resourcebased); electronics/electrical and transport/ automobile industries (both of which are not resource-based).' The two resource-based industries are important because they raise questions about the potential for further developing resource-based manufacturing industries. A natural resource-based industrialization strategy, it has been argued, can bring benefits to economies that produce primary commodities, and several developing countries have tried to go down this route (Yeats, 1991). Markets for processed commodities may be more stable than those for raw commodities, and could in the long run yield more stable and larger secular price increases. The electronics/electrical products industry is the single most important manufacturing sector, making a considerable contribution to the industrialization of the economy. The automobile industry, an example of a heavy Industry-is included because important policy changes have recently resulted from a fundamental reevaluation of the big push strategy introduced in the late 1980s.

\section{Electrical and electronics products}

The increasing importance of industrial electronics has been due to the expanding manufacture of high value-added products such as computers, computer peripherals and telecommunications equipment (Ministry of International Trade and Industry 2006). New highend products include fabricated wafers, mobile phones, telecommunications equipment, computer notebooks and servers. New services, including the design of integrated circuits, prototyping, and testing and failure analysis have also grown and expanded.

The oil palm industry has evolved from a mere producer and exporter of crude palm oil (CPO) into a more diversified entity, creating new downstream and supporting industries. Over the years, it has remained resilient in the face of many challenges and has continued to contribute significantly to the national economy. Its contribution to GDP amounted to RM6.8 billion in 1995 or 5.7 per cent, up from RM3.6 billion in 1985. Among the primary commodities, palm oil is the country's largest export earner, totalling RM13 billion (US $\$ 3.4$ billion). About 250,000 families in Government land schemes and independent smallholdings, as well as 80,000 workers in the private estates of Peninsular Malaysia, are dependent on this industry for their livelihood. Concurrent with the rapid expansion in oil palm planted areas, the number of oil palm mills also increased. At the end of 1995, there were 281 oil palm mills with an annual operating capacity of 50.8 million tonnes of fresh fruit bunches (FFB), 41 refineries and 13 oleochemical manufacturers with an annual operating capacity of 10.15 million tonnes and 0.82 million tonnes, respectively. Processed palm oil exports grew from 3.4 million tonnes to 6.5 million tonnes during the period 1985-95.

Over the 1985-95 period, the country recorded an increase in average yield and total rice production. National yield recorded an increase from 2.7 tonnes per hectare to 3.2 tonnes per hectare during the period. Peninsular Malaysia recorded an average yield of 3.7 tonnes per 
hectare in 1995, while Sarawak and Sabah averaged 1.2 and 2.7 tonnes per hectare, respectively. Total rice production increased from 1.7 million tonnes in 1985 to 2.1 million tonnes in 1995. The eight main granary areas, which accounted for more than 70 per cent of rice production, recorded an increased yield from 3.3 tonnes per hectare in 1985 to 4 tonnes per hectare in 1995. Over the 1985-95 period, domestic production accounted for about 77 per cent of the total domestic consumption. In 1995 importation of rice amounted to 427,570 tonnes valued at RM356.1 million (US\$94 million).

Cocoa production increased from 108,000 tonnes in 1985 to 247,000 tonnes in 1990 but subsequently declined to 132,000 tonnes in 1995. Cocoa remains an important agro-based industry for the country. During the 1990-1995 period, exports of these products have increased by about 48 per cent, from RM307 million (US\$81 million) to about RM453 million (US\$119 million). The cocoa industry is a source of livelihood for about 120,000 smallholder families and employs about 36,000 workers in the estate sector. Additionally, a substantial number is employed in supporting industries such as in processing, grinding and manufacturing. Currently, Malaysia has 10 grinding factories with a production capacity of 125,000 tonnes per year.

The fruit industry is a smallholder-based industry involving 270,000 farmers. In 1995, the area under fruits was 260,600 hectares, and in the year 2010, it is forecasted to increase to 375,000 hectares. For the 1985-95 period, the production of fresh fruits increased at the rate of 4.8 per cent per annum from 638,100 tonnes to $1,019,900$ tonnes. The total value of fresh fruits exported increased from RM72.3 million (US\$19 million) in 1985 to RM170.2 million (US\$45 million) in 1995 (Table 10). The major fruits exported were melons, durians, papaya, banana and starfruit. The exports of processed fruits increased from RM110 million (US\$29 million) in 1985 to RM165 million (US\$43 million) in 1995. However, Malaysia is still a net importer of fruits and fruit products.

The production of vegetables has increased from 540,700 tonnes in 1985 to 718,100 tonnes in 1995 at an average annual growth rate of about 2.9 per cent (Table 11). In the year 2010, it is forecasted that the planted acreage will increase to 86,000 hectares with a production of 1.6 million tonnes (Table 12). The export of vegetables has increased at a rate of 15.2 per cent per annum from RM39 million (US\$10 million) in 1985 to RM160 million (US\$42 million) in 1995. The value of import has increased from RM276 million (US\$73 million) in 1985 to RM683 million (US\$180 million) in 1995.

\section{Empirical review}

Samuelson (1968) in describing economic diversification as an act of investing in a variety of assets mentioned its benefit as that which reduces risk especially in the time of recession, inflation, deflation etc. Economic diversification strives to smooth out unsystematic risk events in a portfolio so that the positive performance of some investments will neutralize the negative performance of others.

An empirical example relating economic diversification to risk reduction and economic growth was the research carried out by Elton and Gruber (1977). They worked out an empirical example of the gains from economic diversification. Their approach was to consider a population of 3,290 securities available for possible inclusion in a portfolio and to consider the average risk over all possible randomly chosen $n$-asset portfolios with equal amounts held in each included asset, for various values of $n$. Their result shows that most of the gains from 
diversification come for $\mathrm{n} \leq 30$ which indicates continuous economic growth.

Oliner and Sichel (2000), Jorgenson (2000) and Whelan (2000) used the endogenous growth model to study the implication of growth rebound in the US economy. Their findings support the assertion of improving economic diversification through other means like information technology which they see as the main sources of the rebound; hence the role of technological progress in agriculture cannot be underestimated. Other researchers like Young (1995) applied the same framework and discovered that the higher growth of output in the newly industrialized countries of East Asia than the rest of the world is almost entirely due to rising in economic diversification which increases labour force participation and empowerment in labour quality (through knowledge accumulation) and not attributable to rapid technological progress. Adebayo (1999) noted this when he said that the neglect of agriculture and the rural economy and the concentration of economic activity in the oil sector was the cause of the current scarcity of raw materials, which has led to heavy imports of raw materials and foodstuff. Muttaka (2015) examined the effect of Nigeria's oil dependency on economic growth. He observed that Nigeria has wasted much of its opportunities to break away from underdevelopment despite its massive natural and human resources endowment due to heavy reliance on her huge crude oil resources, regrettably mismanaged, as the major source of revenue. He identified and discussed some key drivers of economic diversification such as investment, governance and regional dimensions of economic diversification as well as human and natural resources. He maintained that of all the other drivers, good governance remains a prerequisite in building an enabling environment for such diversification.

Onucheyo (2001) earlier predicted the fall in oil prices, when he pointed out that in the $21 \mathrm{st}$ century nuclear, solar, geothermal and other energy sources would be sufficiently developed to meet most of the world's energy requirements. A situation which, according to Onucheyo, raises fears for Nigeria's oil-powered mono-cultural economy. Onucheyo maintained that Nigeria's position in the 21 st century will not depend on its oil, but the development of its agricultural sector and related human resources. Egunjobi (2012) assessed the impact of urban unemployment on economic growth using co-integration and error correction mechanisms. The research thought that income, government expenditure and investment in human resources had a direct impact while urban-unemployment rate had an indirect impact on economic growth. Hence, he recommended diversification in human resources.

\section{Agricultural policy}

Agricultural policy is an official document formulated by the government as a set of the strategic direction of the agricultural sector in Malaysia. Generally, an agricultural policy is formulated for a certain period. The agricultural policy in Malaysia was established in two periods of time; the policy before independence (1948 -1957) and after independence (19572020). During the pre-independence, the agricultural policies were formulated by and for the interest of the British colonial. The emphasis was on plantation crops such as rubber, oil palm and cocoa. On the other hand, the policies after independence mainly addressed the poverty issues among farmers. The policies focused on how to enhance the income of farmers to reduce poverty in the agricultural sector and to minimize the intersectoral inequality between the agricultural and non-agricultural sectors. After independence, Malaysia formulated four agricultural policies namely, the National Agricultural Policy 1,2, 3 (NAPl-3) and the National Agro-food Policy (NAM). 
The Malaya economic plan (1957-1983)

After independence, the government continued the colonial's pre-independence agricultural policy. The government recognized the significant role and contribution of agriculture and set the strategic direction under the Government Economic Development Plan. The policies on agriculture development were published in the First Malaya Plan (1956-1960), Second Malaya Plan (1961-1965), and the First Malaysia Plan (1966-1970). In the early period after independence, the agricultural policy was influenced by the colonial's policy, in which the focus was on the industrial crops for export markets. Large forest land was opened for palm oil and rubber plantations. As a result, until 1970, more than 123,000 ha of palm oil and 131,500 ha of rubber were planted in Malaysia. Throughout this period, agriculture led by rubber and palm oil was the main contributors of Malaysia's economy, providing the benefits of foreign exchange income, capital creation and employment.

Data presentation and discussion

\begin{tabular}{|c|c|c|c|}
\hline \multirow[t]{2}{*}{ Malaysia } & \multirow[b]{2}{*}{1995} & \multirow[b]{2}{*}{2005} & \multirow[b]{2}{*}{2016} \\
\hline & & & \\
\hline \multicolumn{4}{|l|}{ The setting } \\
\hline Population, total (mill.) & 20.5 & 25.7 & 31.6 \\
\hline Rural population, total (mill.) & 9.2 & 8.6 & 7.6 \\
\hline Govt. expenditure on agric. (\%total outlays) & & 3.4 & 2.9 \\
\hline Area harvested, crops (mill. ha) & 5.7 & 6.6 & 7.3 \\
\hline Cropping intensity ratio & 0.9 & 1.0 & 0.9 \\
\hline Total renewable water resources per cap. $\left(\mathrm{m}^{3}\right)$ & 26.596 & 21.698 & 18597 \\
\hline Land area equipped for irrigation (1 $000 \mathrm{ha}$ ) & 363 & 375 & 442 \\
\hline Agric. Area irrigated (\% agric. Area) & & & 5.1 \\
\hline Employment in agriculture $(\%)$ & 20.0 & 14.6 & 11.4 \\
\hline Employment in agriculture, female (\%) & 17.0 & 10.1 & 6.8 \\
\hline Fertilizers use, nitrogen (1000 t nutrients) & & 634.7 & 280.6 \\
\hline Fertilizers use, phosphate (1 000 t nutrients) & & 78.3 & 288.4 \\
\hline Fertilizers use, potash (1 $000 \mathrm{t}$ nutrients) & & 682.5 & 951.0 \\
\hline Agric. Value-added per worker (constant USD) & 11199 & 14.632 & 16735 \\
\hline \multicolumn{4}{|l|}{ Hunger dimensions } \\
\hline Average dietary energy supply (kcal/cap/day) & & 2.810 & 2964 \\
\hline Average dietary energy supply adequacy $(\%)$ & & 121 & 125 \\
\hline Dietary energy supply, cereals/roots/tubers (\%) & & 47 & 44 \\
\hline Prevalence of undernourishment (\%) & & 3.9 & 2.9 \\
\hline \multicolumn{4}{|l|}{ Prevalence of severe food insecurity (\%) } \\
\hline GDP per capita (USD, PPP) & & 18.577 & 25669 \\
\hline Cereal import dependency ratio (\%) & & 86.3 & 72.6 \\
\hline Stunting, children under $5(\%)$ & & 17.2 & 20.7 \\
\hline Wasting children under $5(\%)$ & & & 11.5 \\
\hline Safely managed drinking water (\% pop. Using) & & 93.2 & 92.1 \\
\hline \multicolumn{4}{|l|}{ Food supply } \\
\hline Food production value, net (2004-06 mill. $1 \$)$ & 7427 & 11.127 & 14568 \\
\hline Agriculture, value added (5GDP) & 13 & 8 & 9 \\
\hline Food (excl fish) exports (mill. USD) & 6015 & 7648 & 16150 \\
\hline Food (excl. fish) imports (mill USD) & 2821 & 4456 & 10700 \\
\hline Production indices $(2004-06=100)$ & & & \\
\hline
\end{tabular}




\begin{tabular}{|c|c|c|c|}
\hline Food & 67 & 100 & 131 \\
\hline Crops & 66 & 100 & 118 \\
\hline Cereals & 94 & 103 & 100 \\
\hline Vegetable oils & 53 & 100 & 131 \\
\hline Roots and tubers & 275 & 101 & 105 \\
\hline Fruit and vegetables & 93 & 100 & 136 \\
\hline Sugar & 331 & 103 & 1 \\
\hline Livestock & 87 & 100 & 145 \\
\hline Milk & 91 & 100 & 102 \\
\hline Meat & 89 & 100 & 136 \\
\hline Fish & 86 & 96 & 123 \\
\hline \multicolumn{4}{|l|}{ Net trade (mill. USD) } \\
\hline Cereals and preparations & -711 & -823 & -883 \\
\hline Fruit and vegetables & -260 & -357 & -1482 \\
\hline Meat and meat preparations & -125 & -255 & -681 \\
\hline Dairy products (milk equivalent) & -303 & -333 & -419 \\
\hline Fish & 11 & 112 & -224 \\
\hline \multicolumn{4}{|l|}{ Environment } \\
\hline Forest area (\% total land area) & 67 & 64 & 68 \\
\hline Agricultural area (\% total land area) & 21 & 22 & 26 \\
\hline Freshwater withdrawal (\% tot. renewable) & 0.9 & 1.9 & \\
\hline Terrestrial protected areas ( $\%$ total land area) & & & 19 \\
\hline Organic area (ha) & & 1 & 1 \\
\hline Wood pellet production $(1000 \mathrm{t})$ & & & 310 \\
\hline Emissions in agriculture $\left(\mathrm{CO}_{2}\right.$ eq. $\left.\mathrm{Gg}\right)$ & 11540 & 14095 & 12533 \\
\hline Net emission in land use $\left(\mathrm{CO}_{2}\right.$ eq. $\left.\mathrm{Gg}\right)$ & 126794 & 153534 & -138287 \\
\hline
\end{tabular}

Source: World Development Indicator, 2018.

\begin{tabular}{|l|l|l|l|}
\hline Nigeria & & & \\
\hline & $\mathbf{1 9 9 5}$ & $\mathbf{2 0 0 5}$ & $\mathbf{2 0 1 6}$ \\
\hline The Setting & & & \\
\hline Population, total (mill.) & 108.0 & 138.9 & 190.9 \\
\hline Rural population, total (mill.) & 73.5 & 85.0 & 98.1 \\
\hline Govt. expenditure on agric. (\%total outlays) & & 4.0 & 1.8 \\
\hline Area harvested, crops (mill. ha) & 38.4 & 45.1 & 51.5 \\
\hline Cropping intensity ratio & 1.0 & 1.1 & 1.3 \\
\hline Total renewable water resources per cap. (m $\left.{ }^{3}\right)$ & 2511 & 1945 & 1539 \\
\hline Land area equipped for irrigation (1 000 ha) & 233 & 293 & 293 \\
\hline Agric. Area irrigated (\% agric. Area) & & 0.3 & \\
\hline Employment in agriculture (\%) & 59.2 & 51.2 & 36.3 \\
\hline Employment in agriculture, female (\%) & 54.7 & 44.4 & 26.1 \\
\hline Fertilizers use, nitrogen (1 000 t nutrients) & & 213.2 & 86.5 \\
\hline Fertilizers use, phosphate (1 000 t nutrients) & & 20.7 & 61.5 \\
\hline Fertilizers use, potash (1 000 t nutrients) & & 25.2 & 38.0 \\
\hline Agric. Value added per worker (constant USD) & 1394 & 3019 & 5711 \\
\hline Hunger dimensions & & & \\
\hline
\end{tabular}




\begin{tabular}{|c|c|c|c|}
\hline Average dietary energy supply (kcal/cap/day) & & 2696 & 2518 \\
\hline Average dietary energy supply adequacy (\%) & & 125 & 117 \\
\hline Dietary energy supply, cereals/roots/tubers (\%) & & 63 & 65 \\
\hline Prevalence of undernourishment (\%) & & 6.5 & 11.5 \\
\hline Prevalence of severe food insecurity (\%) & & & 24.8 \\
\hline GDP per capita (USD, PPP) & & 4149 & 5435 \\
\hline Cereal import dependency ratio (\%) & & 16.1 & 19.2 \\
\hline Stunting, children under $5(\%)$ & & 42.8 & 43.6 \\
\hline Wasting children under $5(\%)$ & & 13.4 & 10.8 \\
\hline Safely managed drinking water (\% pop. Using) & & 18.5 & 19.4 \\
\hline \multicolumn{4}{|l|}{ Food supply } \\
\hline Food production value, net (2004-06 mill. 1\$) & 20771 & 30634 & 38311 \\
\hline Agriculture, value added (5GDP) & 24 & 25 & 21 \\
\hline Food (excl fish) exports (mill. USD) & 196 & 566 & 1040 \\
\hline Food (excl. fish) imports (mill USD) & 964 & 2441 & 4566 \\
\hline \multicolumn{4}{|l|}{ Production indices $(2004-06=100)$} \\
\hline Food & 68 & 100 & 125 \\
\hline Crops & 67 & 99 & 119 \\
\hline Cereals & 84 & 99 & 97 \\
\hline Vegetable oils & 62 & 99 & 91 \\
\hline Roots and tubers & 65 & 99 & 126 \\
\hline Fruit and vegetables & 70 & 101 & 129 \\
\hline Sugar & 64 & 100 & 146 \\
\hline Livestock & 73 & 101 & 119 \\
\hline Milk & 93 & 99 & 118 \\
\hline Meat & 71 & 101 & 123 \\
\hline Fish & 64 & 101 & 181 \\
\hline \multicolumn{4}{|l|}{ Net trade (mill. USD) } \\
\hline Cereals and preparations & -211 & -1085 & -1406 \\
\hline Fruit and vegetables & 10 & -43 & -107 \\
\hline Meat and meat preparations & -3 & -4 & -9 \\
\hline Dairy products (milk equivalent) & -272 & -299 & -298 \\
\hline Fish & -125 & -557 & -624 \\
\hline \multicolumn{4}{|l|}{ Environment } \\
\hline Forest area (\% total land area) & 17 & 12 & 7 \\
\hline Agricultural area (\% total land area) & 75 & 80 & 78 \\
\hline Freshwater withdrawal (\% tot. renewable) & & 4.0 & \\
\hline Terrestrial protected areas (\% total land area) & & & 14 \\
\hline Organic area (ha) & & 3 & 52 \\
\hline \multicolumn{4}{|l|}{ Wood pellet production $(1000 \mathrm{t})$} \\
\hline Emissions in agriculture $\left(\mathrm{CO}_{2}\right.$ eq. $\left.\mathrm{Gg}\right)$ & 41404 & 55732 & 67087 \\
\hline Net emission in land use $\left(\mathrm{CO}_{2}\right.$ eq. $\left.\mathrm{Gg}\right)$ & 193372 & 158995 & 191754 \\
\hline
\end{tabular}

Source: World Development Indicator, 2018. 
Value added of agriculture and agro-based industry, 2000 - 2010, Malaysia

\begin{tabular}{|c|c|c|c|c|c|c|c|c|c|}
\hline \multirow[t]{3}{*}{ Commodity } & \multicolumn{3}{|c|}{$\begin{array}{l}\text { RM Million } \\
\text { (in } 1987 \text { prices) }\end{array}$} & \multicolumn{3}{|c|}{ \% of Total } & \multicolumn{3}{|c|}{$\begin{array}{l}\text { Average Annual Growth } \\
\text { Rate }(\%)\end{array}$} \\
\hline & & & & & & & 8MP & & 9MP \\
\hline & 2000 & 2005 & 2010 & 2000 & 2005 & 2010 & Target & Achieved & Target \\
\hline Agriculture & 18,662 & 21,585 & 27.517 & 100.0 & 100.0 & 100.0 & 2.0 & 3.0 & 5.0 \\
\hline $\begin{array}{l}\text { Industrial } \\
\text { Commodities }\end{array}$ & 11,033 & 13,278 & 15,521 & 59.1 & 60.6 & 56.4 & 0.7 & 3.8 & 3.2 \\
\hline Oil palm & 5,860 & 7,915 & 10.068 & 31.4 & 36.7 & 36.6 & 3.4 & 6.2 & 4.9 \\
\hline Forestry and Logging & 3,055 & 3,016 & 2,761 & 16.4 & 13.0 & 10.0 & -5.6 & -0.3 & -1.7 \\
\hline Rubber & 1,868 & 2,264 & 2,554 & 10.0 & 10.5 & 9.3 & 1.1 & 3.9 & 2.4 \\
\hline Cocoa & 250 & 83 & 138 & 1.3 & 0.4 & 0.5 & 0.1 & -19.8 & 10.8 \\
\hline Food Commodities & 7,629 & 8,308 & 11,996 & 40.9 & 39.4 & 43.6 & 4.0 & 1.7 & 7.6 \\
\hline Fisheries & 2,493 & 2,389 & 3,875 & 13.4 & 12.6 & 14.1 & 4.1 & -0.9 & 10.2 \\
\hline Livestock & 1,520 & 2,089 & 2,483 & 8.1 & 8.1 & 9.0 & 6.0 & 6.6 & 3.5 \\
\hline Padi & 590 & 632 & 988 & 3.2 & 3.4 & 3.6 & 2.7 & 1.4 & 9.4 \\
\hline Other Agriculture $^{8}$ & 3,026 & 3,198 & 4,650 & 16.2 & 15.2 & 16.9 & 3.2 & 1.1 & 7.8 \\
\hline Agro-Based Industry & 13,584 & 16,928 & 22,221 & 100.0 & 100.0 & 100.0 & 4.0 & 4.5 & 5.6 \\
\hline $\begin{array}{l}\text { Vegetable } \\
\text { Animal Oils \& } \\
\text { Fats }\end{array}$ & 2,526 & 3,639 & 5,614 & 18.6 & 21.5 & 25.3 & 6.3 & 7.6 & 9.1 \\
\hline $\begin{array}{ll}\text { Other } & \text { Food } \\
\text { Processing, } & \\
\text { Beverages } & \& \\
\text { Tobacco } & \\
\end{array}$ & 4,010 & 4,790 & 6,333 & 29.5 & 28.3 & 28.5 & 2.0 & 3.6 & 5.7 \\
\hline $\begin{array}{l}\text { Woof Products } \\
\text { including } \\
\text { Furniture } \\
\end{array}$ & 2,934 & 2,972 & 3,761 & 21.6 & 17.6 & 16.9 & 0.6 & 0.3 & 4.8 \\
\hline $\begin{array}{l}\text { Paper \& Paper } \\
\text { Products, Printing } \\
\text { \&Publishing }\end{array}$ & 2,293 & 2,640 & 3,275 & 16.9 & 15.6 & 14.7 & 3.4 & 2.9 & 4.4 \\
\hline $\begin{array}{l}\text { Rubber Processing \& } \\
\text { Products }\end{array}$ & 1,821 & 2,887 & 3,238 & 13.4 & 17.1 & 14.6 & 4.7 & 9.7 & 2.3 \\
\hline $\begin{array}{l}\text { Total Agriculture and } \\
\text { Agro-Based } \\
\text { Industry }\end{array}$ & 32,246 & 38,513 & 49,738 & & & & 2.7 & 3.6 & 5.2 \\
\hline $\begin{array}{l}\text { Gross Domestic } \\
\text { Product } \\
\text { Purchaser's } \\
\text { Prices }\end{array}$ & 210,558 & 262,029 & 351,297 & & & & & 4.5 & 6.0 \\
\hline
\end{tabular}

Source: Department of Statistics and Economic Planning Unit, Malaysia, 2012. 
Value added of agriculture and agro-based industry, 1990-2010, Malaysia.

\begin{tabular}{|l|l|l|l|l|l|}
\hline Commodity & \multicolumn{2}{l|}{$\begin{array}{l}\text { RM Million } \\
\text { (in 1987 prices) }\end{array}$} & \\
\hline & \multicolumn{2}{l|}{} & & \\
\hline & 1990 & 1995 & 2000 & 2005 & 2010 \\
\hline Agriculture & $\begin{array}{l}17,308 \\
(16.33)\end{array}$ & $\begin{array}{l}17,114 \\
(10.27)\end{array}$ & $\begin{array}{l}18,662 \\
(8.86)\end{array}$ & $\begin{array}{l}21,585 \\
(8.24)\end{array}$ & $\begin{array}{l}27.517 \\
(7.83)\end{array}$ \\
\hline Industrial Commodities & 12,041 & 10,980 & 11,033 & 13,278 & 15,521 \\
\hline Oil palm & 3,350 & 4,235 & 5,860 & 7,915 & 10.068 \\
\hline Forestry and Logging & 5,194 & 4,139 & 3,055 & 3,016 & 2,761 \\
\hline Rubber & 2,634 & 2,129 & 1,868 & 2,264 & 2,554 \\
\hline Cocoa & 863 & 477 & 250 & 83 & 138 \\
\hline Food Commodities & 5,267 & 6,135 & 7,629 & 8,308 & 11,996 \\
\hline Fisheries & 1,534 & 1.964 & 2,493 & 2,389 & 3,875 \\
\hline Livestock & 1,098 & 1,531 & 1,520 & 2,089 & 2,483 \\
\hline Other Agriculture 8 & 2,635 & 2,640 & 3,616 & 3,830 & 5,638 \\
\hline Agro-Based Industry & 8,102 & 11,174 & 13,584 & 16,928 & 22,221 \\
& $(7.64)$ & $(6.71)$ & $(6.45)$ & $(6.46)$ & $(6.33)$ \\
\hline Vegetable and Animal Oils \& Fats & 1,036 & 1,203 & 2,526 & 3,639 & 5,614 \\
\hline Other Food Processing, Beverages \& Tobacco & 2,642 & 3,504 & 4,010 & 4,790 & 6,333 \\
\hline Woof Products including Furniture & 1,776 & 3,030 & 2,934 & 2,972 & 3,761 \\
\hline $\begin{array}{l}\text { Paper \& Paper Products, printing \& } \\
\text { Publishing }\end{array}$ & & 1,888 & 2,293 & 2,640 & 3,275 \\
\hline Rubber Processing \& Products & 1,532 & 1,549 & 1,821 & 2,887 & 3,238 \\
\hline Total Agriculture and Agro-Based Industry & 25,410 & 28,288 & 32,246 & 38,513 & 49,738 \\
& $(23.97)$ & $(16.98)$ & $(15.31)$ & $(14.70)$ & $(14.16)$ \\
\hline Gross Domestic Product at Purchaser's Prices & 105.977 & 166,625 & 210,558 & 262,029 & 351,297 \\
\hline
\end{tabular}

Source: Department of Statistics, Malaysia, 2012. 
Agriculture and agro-based manufactured export, 2000-2010, Malaysia

\begin{tabular}{|c|c|c|c|c|c|c|c|c|}
\hline \multirow[t]{2}{*}{ Commodity } & \multicolumn{3}{|c|}{ RM Million } & \multicolumn{3}{|c|}{$\%$ of Total } & \multicolumn{2}{|c|}{$\begin{array}{l}\text { Average Annual } \\
\text { Growth Rate (\%) }\end{array}$} \\
\hline & 2000 & 2005 & 2010 & 2000 & 2005 & 2010 & $\begin{array}{l}\text { 8MP } \\
\text { Achieved }\end{array}$ & $\begin{array}{l}\text { 9MP } \\
\text { Target }\end{array}$ \\
\hline Agriculture Exports & 22,892 & 37,421 & 54,992 & 48.1 & 50.0 & 47.5 & 10.3 & 8.0 \\
\hline$\%$ to Total Export & 6.1 & 7.0 & 6.8 & & & & & \\
\hline Industrial Commodities & 18,428 & 31,509 & 37,244 & 38.7 & 42.1 & 32.2 & 11.3 & 3.4 \\
\hline Palm Oil & 9,948 & 19,036 & 26,735 & 20.9 & 25.4 & 23.1 & 13.9 & 7.0 \\
\hline Rubber & 2,571 & 5,787 & 5,156 & 5.4 & 7.7 & 4.5 & 17.6 & -2.3 \\
\hline Sawlogs & 2,489 & 2,465 & 2,100 & 5.2 & 3.3 & 1.8 & -0.2 & -3.2 \\
\hline Sawtimber & 3,020 & 4,051 & 2,995 & 6.3 & 5.4 & 2.6 & 6.0 & -5.9 \\
\hline Cocoa & 33 & 50 & 128 & 0.1 & 0.1 & 0.1 & 8.8 & 20.5 \\
\hline Pepper & 367 & 120 & 130 & 0.8 & 0.2 & 0.1 & -20.0 & 1.6 \\
\hline Food commodities & 4.464 & 5,913 & 17,748 & 9.4 & 7.9 & 15.3 & 5.8 & 24.6 \\
\hline $\begin{array}{l}\text { Agro-Based } \\
\text { Manufactured } \\
\text { Exports }\end{array}$ & 24,686 & 37,442 & 60,660 & 51.9 & 50.0 & 52.5 & 8.7 & 10.0 \\
\hline$\%$ to Total Exports & 6.6 & 7.0 & 7.6 & & & & & \\
\hline Food & 4,509 & 8,627 & 15,803 & 9.5 & 11.5 & 13.7 & 13.9 & 12.9 \\
\hline Beverages and Tobacco & 1,207 & 1,755 & 2,446 & 2.5 & 2.3 & 2.1 & 7.8 & 6.9 \\
\hline Wood Product & 6,901 & 9,665 & 13,909 & 14.3 & 12.9 & 12.0 & 7.3 & \\
\hline Furniture and Parts & 6,077 & 8,454 & 14,335 & 12.8 & 11.3 & 12.4 & 6.8 & 7.6 \\
\hline Paper and Paper Product & 1,397 & 2,018 & 2,799 & 2.9 & 2.7 & 2.4 & 7.6 & 11.1 \\
\hline Rubber product & 4,695 & 6,923 & 11,368 & 9.9 & 9.3 & 9.8 & 8.1 & 6.8 \\
\hline $\begin{array}{c}\text { Total Agriculture and } \\
\text { Agro-Based Exports }\end{array}$ & 47,578 & 74,863 & 115,652 & 100.0 & 100.0 & 100.0 & 9.5 & 10.4 \\
\hline$\%$ to Total Exports & 12.7 & 14.0 & 14.4 & & & & & 9.1 \\
\hline Total Exports & 373,270 & 533,790 & 803,163 & & & & 7.4 & 8.5 \\
\hline
\end{tabular}

Source: Department of Statistics and Economic Planning, Malaysia, 2012. 
Employment and value-added worker in agriculture and agro-based industry, 2000-2010, Malaysia

\begin{tabular}{|c|c|c|c|c|c|c|}
\hline & \multicolumn{3}{|c|}{ RM Million } & \multicolumn{3}{|c|}{$\begin{array}{l}\text { Average Annual } \\
\text { Growth Rate (\%) }\end{array}$} \\
\hline & \multirow[t]{2}{*}{2000} & \multirow[t]{2}{*}{2005} & \multirow[t]{2}{*}{2010} & \multicolumn{2}{|l|}{ 8MP } & \multirow[t]{2}{*}{ 9MP Target } \\
\hline & & & & Achieved & Target & \\
\hline $\begin{array}{l}\text { Agriculture Employment } \\
\text { Number ('000) }\end{array}$ & $1,423.0$ & $1,405.7$ & $1,323.8$ & -1.4 & -0.2 & -1.2 \\
\hline$\%$ of Total Employment & 15.3 & 13.3 & 10.9 & & & 6.2 \\
\hline $\begin{array}{l}\text { Value Added Per Worker } \\
\text { (RM in } 1987 \text { prices) }\end{array}$ & 13,115 & 15,752 & 21,299 & 4.5 & 3.7 & \\
\hline $\begin{array}{l}\text { Agro-Based Employment } \\
\text { Number ('000) }\end{array}$ & 844.0 & 981.9 & $1,110.2$ & & 3.1 & 2.5 \\
\hline$\%$ of Total Employment & 9.1 & 9.3 & 9.1 & & & \\
\hline $\begin{array}{l}\text { Value Added Per Worker } \\
\text { (RM in } 1987 \text { prices) }\end{array}$ & 16,107 & 17,002 & 19,688 & & 1.1 & 3.0 \\
\hline $\begin{array}{l}\text { Total Employment in } \\
\text { Agriculture and Agro- } \\
\text { Based Industry }\end{array}$ & $2,267.0$ & $2,387.6$ & $2,434.0$ & & 1.0 & 0.4 \\
\hline$\%$ of Total Employment & 24.4 & 21.9 & 20.3 & & & \\
\hline
\end{tabular}

Source: Department of Statistics and Economic Planning, Malaysia, 2012. 
Largest Public Malaysian Companies

Malaysia has 17 companies that rank in the Forbes Global 2014 ranking.

\begin{tabular}{|c|c|c|c|c|c|c|}
\hline $\begin{array}{l}\text { World } \\
\text { Rank }\end{array}$ & Company & Industry & $\begin{array}{l}\text { Revenue } \\
\quad \text { (billion } \\
\text { \$) }\end{array}$ & $\begin{array}{l}\text { Profit } \\
\quad \text { (billion } \\
\$ \text { ) }\end{array}$ & $\begin{array}{l}\text { Assets } \\
\quad \text { (billion } \\
\$ \text { ) }\end{array}$ & $\begin{array}{l}\text { Market } \\
\quad \text { value } \\
\text { (billion } \\
\text { \$) }\end{array}$ \\
\hline 326 & Maybank & Banking & 9.7 & 2.1 & 171.1 & 26.3 \\
\hline 443 & Tenaga Nasional & Utilities & 12 & 1.6 & 31.3 & 20.7 \\
\hline 460 & $\begin{array}{l}\text { CIMB Group } \\
\text { Holdings }\end{array}$ & Banking & 6.8 & 1.4 & 113.2 & 18.1 \\
\hline 585 & $\begin{array}{ll}\text { Public } & \text { Bank } \\
\text { Berhad } & \end{array}$ & Banking & 4.6 & 1.3 & 93.3 & 20.6 \\
\hline 598 & Sime Darby & Conglomerates & 14.4 & 1.1 & 15.2 & 17.1 \\
\hline 861 & Axiata Group & $\begin{array}{l}\text { Telecommunications } \\
\text { Services }\end{array}$ & 5.8 & 0.8 & 13.3 & 17.7 \\
\hline 915 & Genting & $\begin{array}{l}\text { Hotels, Restaurants \& } \\
\text { Leisure }\end{array}$ & 5.6 & 0.6 & 21.8 & 11.4 \\
\hline 1052 & RHB Capital & Banking & 3.0 & 0.6 & 58.3 & 6.6 \\
\hline 1062 & Petronas Chemical & Oil \& Gas Operations & 4.8 & 1 & 8.5 & 16.7 \\
\hline 1121 & AMMB Holdings & Banking & 2.6 & 0.5 & 40 & 6.6 \\
\hline 1246 & $\begin{array}{l}\text { Hong Leong } \\
\text { Financial } \\
\text { Group }\end{array}$ & Banking & 2.5 & 0.5 & 56 & 5.1 \\
\hline 1276 & MISC Berhad & Transportation & 2.8 & 0.7 & 12.3 & 9.4 \\
\hline 1308 & Petronas Gas & Oil \& Gas Operations & 1.2 & 0.7 & 4 & 14.7 \\
\hline 1333 & YTL & Utilities & 6.3 & 0.5 & 18.5 & 4.9 \\
\hline 1344 & Maxis & $\begin{array}{l}\text { Telecommunications } \\
\text { Services }\end{array}$ & 2.9 & 0.6 & 5.3 & 16 \\
\hline 1481 & PetronasDagangan & Oil \& Gas Operations & 10.3 & 0.3 & 3.1 & 9.3 \\
\hline 1567 & IOI Group & $\begin{array}{c}\text { Food, Drink \& } \\
\text { Tobacco }\end{array}$ & 3.9 & 0.5 & 7.8 & 9.3 \\
\hline
\end{tabular}

Source: Forbes Global ranking for 2014.

Discussion and conclusion

A lot has to be learnt from Malaysia if Nigeria's mono-economy must give way to the productive development of various sectors of its economy. In Malaysia, the net value of food production, fish export, food, crop, cereals, vegetable oils, root and tubers, fruits and vegetables, milk, meat, etc. showed tremendous growth from 1995 to 2016, while Nigeria's economic performances in the same aspects are dwindling despite its factor endowments which may be considered better than Malaysia's factor endowments.

Nigeria economy must be diversified to enhance stable and viable sustainable and economic growth for the people of Nigeria to alleviate the current hardship being experienced across the nation. 


\section{References}

Adebayo, O.O. (1999), "Nigeria external debt crisis: Its management." Lagos: Malt House Press Limited.

Adesoye, B.A., Adelowokan, O.A., Maku, E.O. \&Salau, S.O. (2018). Enhancing agricultural value chain for economic diversification in Nigeria. African Journal of Economic Review 6(1):103-118.

Ahmad, T.M.A. and Suntharalingman, C. (2009). Transformation and economic growth of the Malaysian agricultural sector.Economic and Technology Management Review. 2(4): 1-10.

Egunjobi, T.A. (2012). Impact of unemployment and poverty on economic growth in Nigeria. Elton, E.J. and Gruber, M.J. "Risk reduction and portfolio size: An analytic solution, "Journal of Business 50 (October 1977), pp. 415-37.

Food and Agricultural Organization Statistics, FAOSTA.

Hisch, C. (1998). What explains the industrial revolution in East Asia? Evidence from factor markets. The University of California.

Jorgenson, D.W. \& Stiroh, K. J. (2000). Raising the speed limit versus economic growth in the information age. USA: Harvard University.

Muttaka, M. (2015). The intrigues of Nigeria's diversification strategy. [Online]. Available:http://www.dailytrust.com.ngldailylbusiness/43325-the-intrigues-of-nigeria-sdiversification-Strategy.

Oliner, S.D. \&Sichel, D. E. (2000). "The resurgence of growth in the late 1990s: Is information technology the story?" Federal Reserve Board, Finance and Economics Discussion Series Paper number 20.

Onucheyo (2001). Agriculture and the economic future of Nigeria. Available:http://www.wazobia.biafranigeria.com/

Samuelson, P. (1967). "General proof that diversification pays," Journal of Financial and Quantitative Analysis, 2: 1-13.

Whelan, K. (2000). Computers, obsolescence and productivity. Federal Reserve Board, Finance and Economics Discussion Series Paper No.20.

Young, A. (1995). The tyranny of numbers: Confronting the statistical reality of the East Asian growth experience. Quarterly Journal of Economics, 110: 641-680.

Malaysia; ANZ Business: http://www.anzbusiness.com.

World Bank (2016). World Development Indicators, Washington DC: World Bank.

World Bank (2018). World Development Indicators, Washington DC: World Bank 
National Bureau of Statistics (2015). Nigeria's gross domestic product, Fourth Quarter, 2014.

Lim, C. (1973). Economic growth and development in West Asia 1947-1970.

Yeats, A.J. (1991). Do natural resource-based industrialization strategies convey important price benefits for commodity-exporting developing countries? World Bank Working Paper, WP55b.

Yusof, Z.A. (2007). Economic diversification: The case of Malaysia. Revenue Watch Institute, Malaysia. 